Проприальный характер данных единиц, кажется, не вызывает сомнений. Название пандемии позволяет безошибочно определить онимический объект и его характерные черты; оно отсылает к определенному историческому событию, однозначно ассоциируется с определенной территорией, может также непосредственно служить источником информации о соматических симптомах, характерных для данного заболевания. В то же время при анализе единиц такого типа нелегко определить их место в ономастической системе; неясно, следует ли считать их именами собственными исторических событий либо именами собственными болезней.

DOI $10.31168 / 7996-2700-3.123$

\author{
Е. С. Узенёва \\ Институт славяноведения РАН \\ Москва, Россия \\ lenuzen@mail.ru
}

\title{
О языке и культуре славян-мусульман Северной Греции: случай Ксанти
}

В докладе будут представлены предварительные итоги исследования современного состояния языка и традиционной культуры одного из архаических анклавов Балканского полуострова - округа Ксанти, где в горах компактно проживают славяне-мусульмане, помаки (этнические болгары), представляющие собой миноритарную этноязыковую и культурно-конфессиональную группу, существующую в течение длительного времени в иноязычном и инорелигиозном окружении (православные греки).

Автор опирается на собственные полевые материалы, собранные во время двух этнолингвистических экспедиций, осуществленных в 2018 и 2019 гг. совместно с К. А. Климовой, доцентом кафедры новогреческой филологии филологического факультета МГУ им. М. В. Ломоносова. Всего было обследовано 13 сел, опрошено 35 информантов в возрасте 18-75 лет.

(C) Узенёва Е. С., 2019 
Некоторые ученые (в том числе А. А. Дуличенко [2011]) считают, что у помаков Греции (в греческой традиции славянофоны) существует свой литературный микроязык: написаны грамматика и толковый словарь (на основе греческого алфавита), изданы учебники, хрестоматии диалектных текстов (в латинской графике, с греческими толкованиями), в отдельных селах велось факультативное преподавание языка, функционируют СМИ на помакском, переводится литература. Другая точка зрения поддерживает идею существования бесписьменного языка (диалекта, говора). Мы придерживаемся мнения о том, что это южнородопские говоры юго-восточных (рупских) говоров болгарской диалектной зоны.

Сами носители часто приводили факт отсутствия собственной азбуки как аргумент в пользу «несуществования» помакского языка. В сознании информантов их язык (нашо думенье) представляет собой смесь турецкого, греческого и «славянского» языков. В регионе имеет место ситуация полиглоссии:

- греческий язык (государственный язык: администрация, СМИ, обучение в средней и высшей школе);

- турецкий язык (язык конфессии и обучения в начальной школе);

- арабский язык (язык Корана);

- помакский говор - язык семейного общения и традиционной культуры, фольклора.

Этот факт поддерживает и наличие множественной, «колеблющейся» идентичности помаков, которые, однако, сохраняют свой язык, традиционный уклад и культуру.

Помаки Греции, живущие в изоляции в инокультурном и иноконфессиональном окружении, утратили под влиянием ислама часть календарных обрядов, характерных для болгар-мусульман в соседних областях Болгарии, но старые, как христианские, так и языческие, верования консервировались в названии месяцев, ср., например, Големил 'январь', букв. «большой», Малкошан 'февраль', букв. «маленький», Марта 'март' (женское имя, так в фольклоре называют сестру 11 братьев-месяцев), Лошко / Ечко 'апрель', букв. «плохой», Тодорски 'май' (когда отмечают день св. Федора), Марински 'июль' (этот месяц включает день памяти св. Марины), Ягус 'август', Руен 'сентябрь', Димитровски 'октябрь' (месяц, когда отмечают день св. Димитрия), 
Касъм 'ноябрь' и обозначение всей осени', Никулски 'декабрь', связанный с почитанием св. Николая-чудотворца.

Сохранился в селах Ксанти (с. Пахни) и окказиональный зимний ритуал - обход «волчатников» со шкурой убитого волка, которого носили по селу, собирая продукты и деньги для мечети; и мартовские обряды (изготовление украшений-оберегов из разноцветных шерстяных ниток марта, маретница); и верования, связанные с так называемой мартовской старухой (Баба Марта), отправившейся в первые дни месяца в горы пасти овец, замерзшей там и превратившейся в камень (архаичный мотив петрификации). Ср. также обозначения нескольких теплых дней зимой - Бабине дене.

Бо́льшая часть турцизмов в терминологии народной культуры представлена в похоронной (меит 'покойник', кефин 'саван', табут 'гроб', дженезе 'погребение', мезар 'могила', мезарльк 'кладбище', девир 'обряд прощения долгов умершему', кефарет 'ритуал поминовения покойного на седьмой день после смерти', мевлюд 'молитва о покойном', дженнет 'рай’ и др.) и родинной обрядности (калъм 'хлеб и сладости, которые раздают соседям, когда нарекают имя ребенку', сюнет 'ритуал обрезания', хатъм 'обряд посвящения в ислам детей'), а также в народной мифологии (джинья ‘злые духи', щейтан 'дьявол', евлия 'святой человек, обладающий сверхъестественными способностями', еждърхо 'летающий змей, дракон', бешибир, муска, хамалил', коранчик 'мусульманский оберег', зарар 'зло, порча' и др.), что обусловлено влиянием мусульманской религии.

Дуличенко А. А. Основы славянской филологии : в 2 т. Ополе, 2011.

\footnotetext{
${ }^{1}$ Отметим, что у болгар-мусульман Болгарии праздник Касъм, 26.X/8.XI, приходящийся на православный праздник - день св. Димитрия, Димитровден, завершал животноводческий цикл, в этот день с пастухами расплачивались за работу.
} 